Vol.48, Special : pp. 243-250, October 2005 ISSN 1516-8913 Printed in Brazil
BRAZILIAN ARCHIVES OF BIOLOGY AND TECHNOLOGY

AN INTERNATIONAL JOURNAL

\title{
Ordered Mesoporous Silica Carrier System Applied in Nanobiothecnology
}

\author{
Andreza de Sousa and Edésia Martins Barros de Sousa* \\ Centro de Desenvolvimento da Tecnologia Nuclear; CDTN/CNEN; Rua Professor Mário Werneck, s/n; Campus \\ Universitário; 30123-970; sousaem@urano.cdtn.br; Belo Horizonte - MG - Brasil
}

\begin{abstract}
Ordered mesoporous materials like SBA15 possess a network of channels and pores of well-defined size in the nanoscale range $(2-50 \mathrm{~nm})$. This particular pore architecture makes them suitable candidates for hosting and delivery under appropriate conditions of a variety of molecules of pharmaceutical interest, including radiopharmaceuticals. The characteristics of SBA-15 prepared in different temperatures and the behavior of this system regarding microencapsulation of a model drug were investigated. The calcined samples were formed in $0.2 \mathrm{~g}$ disks and were soaked in a solution of atenolol used as a model drug. The modification of the aging temperature provoked changes in the structure of the pores, indicating the presence of microporosity and connections between mesopores. Aging the materials at a higher temperature resulted in no microporosity and this fact influenced the control of the release of the model drug.
\end{abstract}

Key words: Mesoporous materials, drug delivery system, cancer treatment, SBA15.

\section{INTRODUCTION}

A wide range of materials has been investigated for use in the human body (Ragel et al., 2002,). One class of useful devices that can be created with biocompatible materials is the implantable drug delivery device (Langer, 1999). The development of modern drug delivery technology has led to sophisticated systems that allow drug targeting and a sustained or controlled release of drug substances. These novel systems have made possible cancer treatment with significantly reduced side effects, and have enabled new and better chemotherapeutic regimens using existing pharmaceuticals. (Moses et al., 2003) The administration of drugs by implantation or injection as a drug delivery system provides advantages over conventional drug therapies.
Because the drug is delivered locally rather than systemically, harmful side effects that normally occur are minimized. The entire drug dose needed for a desired period is administered at one time and released in a controlled manner. Other potential advantages include drug targeting, improved compliance and comfort. (Marcucci and Lefoulon, 2004)

The availability of various types of materials generally referred to as biomaterials that can be introduced into the body without being rejected as a result of the inflammation process at the implantation site, make such an approach possible. A number of different systems have been studied for controlled drug delivery as hosts for radiopharmaceuticals, such as biodegradable polymers (Shin et al., 2001), and ceramics (Doadrio et al., 2004). Mesoporous materials

\footnotetext{
*Author for correspondence
} 
based on silica are currently a field of intensive activity because of their high potential in a very broad range of applications. A series of inorganic mesostructures, like MCM41, HMS, SBAn etc, have been synthesized with different templating schemes (Zhao et al., 1998, Luan et. al, 1999, Hata et al., 1999). In most cases, ionic and neutral surfactants have been employed as templates to direct the mesophase formation based on the electrostatic and hydrogen-bonding interaction. These mesoporous materials can be used as medical devices because of the presence of larger pores and well-defined structure. They present high surface areas, above $1000 \mathrm{~m} 2 / \mathrm{g}$, and ordered mesopores ranging from $2.0 \mathrm{~nm}$ to several tens of nanometes, depending on the conditions of synthesis. For applications in drug delivery systems (Sousa, et al., 2004, Exner et al, 2005, Zeng, et al., 2005, Zeleňák et al., 2005), the development of mesoporous materials offers new possibilities for incorporating biological agents within a silica sample and for controlling the release kinetics from the matrix because of its well-arranged structure. The delivery of these molecules was once considered impossible because of the difficulty associated with the diffusion of large molecules through the materials of conventional drug delivery systems. These organic substances are normally very large in size, and one can anticipate that mesoporous silica would have a potential for encapsulating bioactive molecules by utilizing ordered mesopores.

Indeed, the release kinetics from the matrix as a result of its well-arranged structure can be altered by changing the pore size. For the SBA-15, some studies (Galarneau et al., 2003, and Krut, et al., 2000) have shown that the microporosity could be observed only in the cases of samples prepared at aging temperature between $40{ }^{\circ} \mathrm{C}$ and $90{ }^{\circ} \mathrm{C}$. No microporosity was observed for the solid prepared at aging temperature above $100{ }^{\circ} \mathrm{C}$.

Taking all these considerations into account, the potential of the mesoporous structure type for hosting and delivery of drugs under appropriate conditions using a model molecule was explored. For this purpose, four different aging temperatures were used in the synthesis, and the performance of the SBA-15 for hosting radiopharmaceuticals was evaluated by using a model drug.

\section{MATERIALS AND METHODS}

\section{Synthesis of materials}

The preparation of mesoporous materials was initiated with the dissolution of surfactant P123 in distilled water and strong acid. Tetraethyl orthosilicate (TEOS) was then added with stirring. The mixture was heated for $24 \mathrm{~h}$ at the aging temperature $\left(60,80,100\right.$ and $\left.130{ }^{\circ} \mathrm{C}\right)$ under static conditions. All materials, named as SBA15-60, SBA15-80, SBA15-100, and SBA15-130, according to aging temperature, were filtered and dried at $40{ }^{\circ} \mathrm{C}$. The surfactant was removed by calcination at $550{ }^{\circ} \mathrm{C}$ during five hours.

\section{Adsorption of model drug}

To evaluate the performance of the SBA-15 for hosting radiopharmaceuticals, the model drug used was atenolol. The initial calcined powders (SBA15 at a different aging temperature) were formed into $0.25 \mathrm{~g}$ disks by uniaxial pressure 1.5 MPa). The disks were soaked in a saturated solution of atenolol $(6.67 \mathrm{mg} / \mathrm{mL})$ for four days at room temperature.

\section{Assays of delivery of model drug}

The in vitro study of atenolol delivery from the materials was performed as follows. The release profile was obtained by soaking the disks in $30 \mathrm{~mL}$ of a simulated body fluid (SBF) (Kokubo et al., 1990) at room temperature. UV spectrometry (UVVis Shimadzu, model 2401) was the analytical method used for monitoring the amount of drug delivered as a function of time.

\section{Characterization}

Surface area and pore sizes of the materials were determined by $\mathrm{N}_{2}$ adsorption using the $\mathrm{BJH}$ method in an Autosorb - Quantachrome NOVA 1200.

The drug presence in SBA-15 was characterized by Fourier Transform Infrared Spectroscopy (FTIR), on a PERKIN-ELMER 1760-X spectrophotometer in the range of $4000-400 \mathrm{~cm}^{-1}$. The FTIR spectra were recorded at room temperature in $\mathrm{KBr}$ pellets.

\section{RESULTS AND DISCUSSION}

Nitrogen isotherms and pore distribution of calcined SBA15-60, SBA15-80, SBA15-100, and 
SBA15-130 are shown in Figs. 1 and 2, respectively.

These results are summarized in Table 1, which shows the different pore sizes in the samples. It is possible to observe a steady increase of the mesopore size when the aging temperature was above $60{ }^{\circ} \mathrm{C}$. Thus, it is possible to incorporate molecules of the most varied dimensions.

A typical adsorption isotherm with a $\mathrm{H} 1$ hysteresis by the IUPAC classification is observed, which is associated with the presence of a mesoporous matrix. The $\mathrm{p} / \mathrm{p}_{0}$ position of the inflection range from 0.60 to 0.80 confirms this porous structural characteristic. Some differences had been observed in the adsorption isotherms as a function of the aging temperature. It can be observed that the relative pressure of pore filling increases with the aging temperature. So, for samples treated at low temperatures, the existence of micropores in the calcined SBA15 should be observed, and for materials aged at higher temperature, no microporosity was present. This fact can be used to favor the control of the release of the drug model.

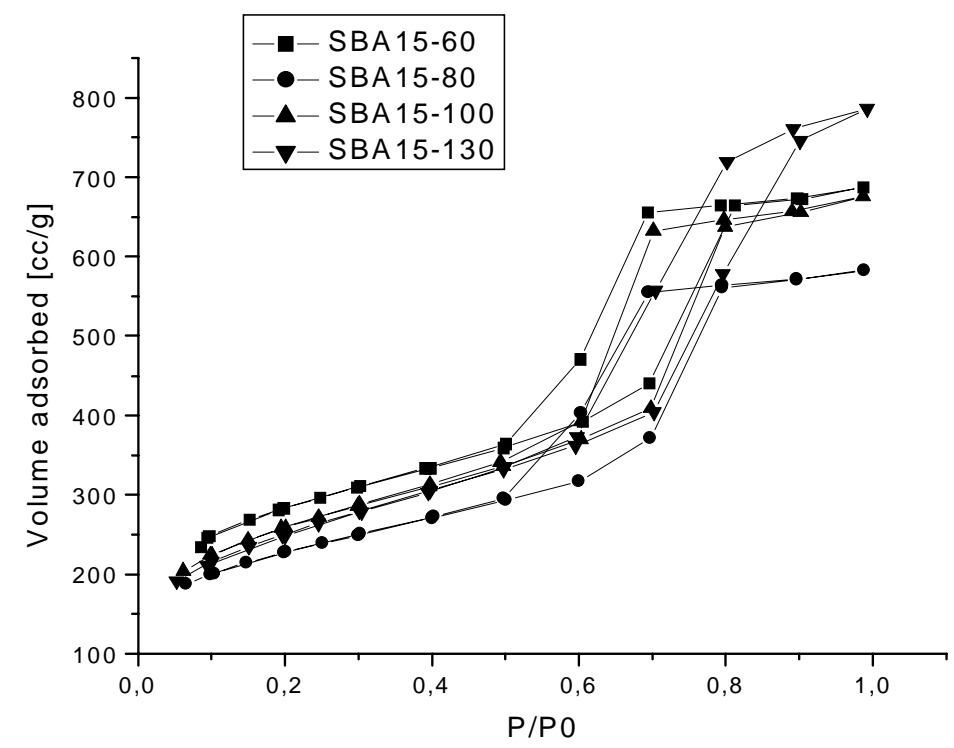

Figure 1 - Nitrogen adsorptions isotherms of of calcined $\mathrm{SBA}^{15-60}, \mathrm{SBA}^{15-80}, \mathrm{SBA}^{15-100}$, and $\mathrm{SBA}^{15-130}$

Table 1 - Nitrogen adsorption results

\begin{tabular}{cccc}
\hline Sample & D $(\mathbf{n m})$ & $\mathbf{V}_{\mathbf{p}}(\mathbf{c c} / \mathbf{g})$ & $\mathbf{S}\left(\mathbf{m}^{2}\right)$ \\
\hline SBA $^{15-60}$ & 4.45 & 4320 & 954 \\
SBA $^{15-80}$ & 4.70 & 3523 & 765 \\
SBA $^{15-100}$ & 4.71 & 5104 & 887 \\
SBA $^{15-130}$ & 5.60 & 3398 & 867 \\
SBA $^{15-100} /$ drug & 7.00 & 1654 & 244 \\
\hline
\end{tabular}



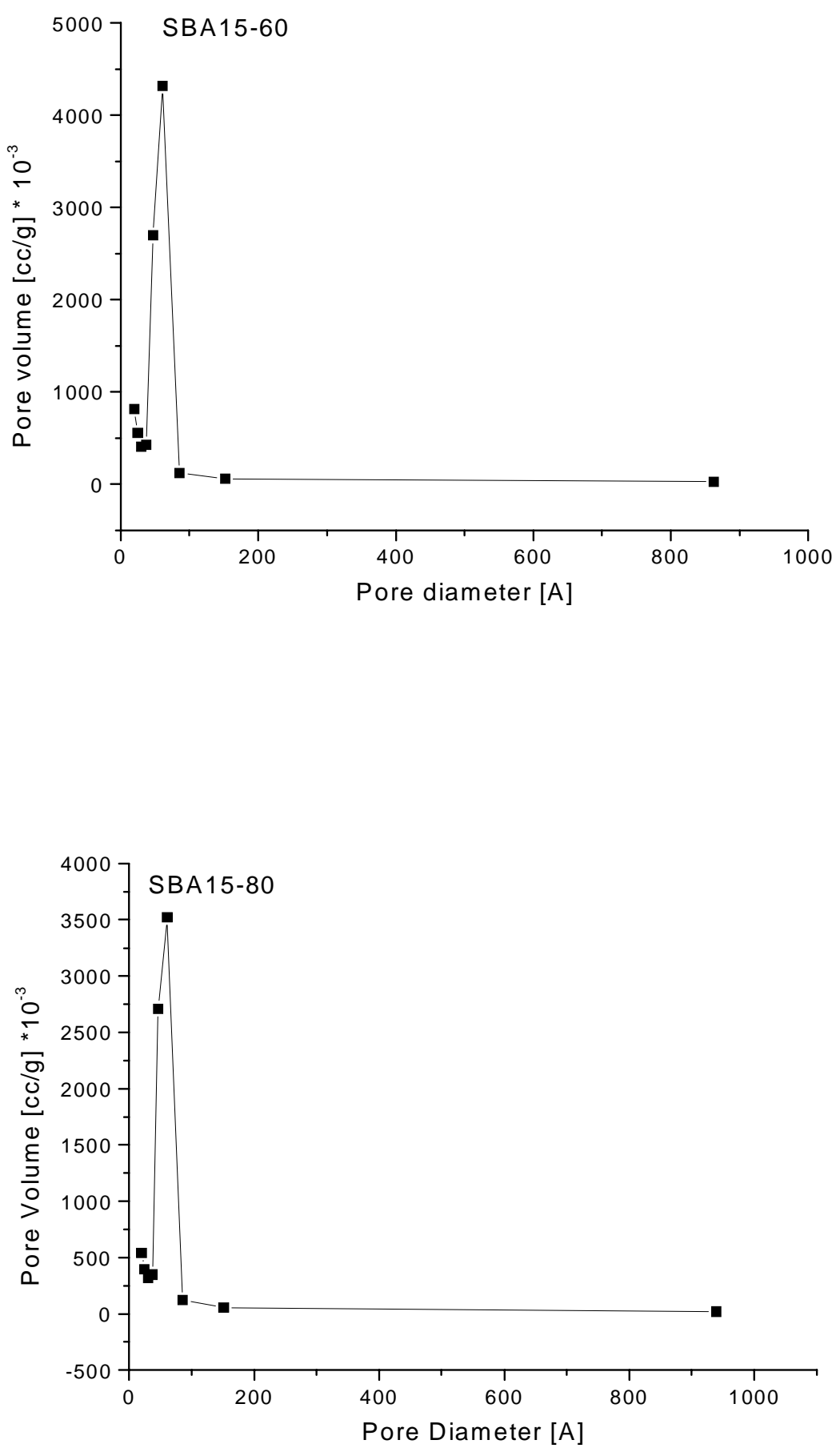

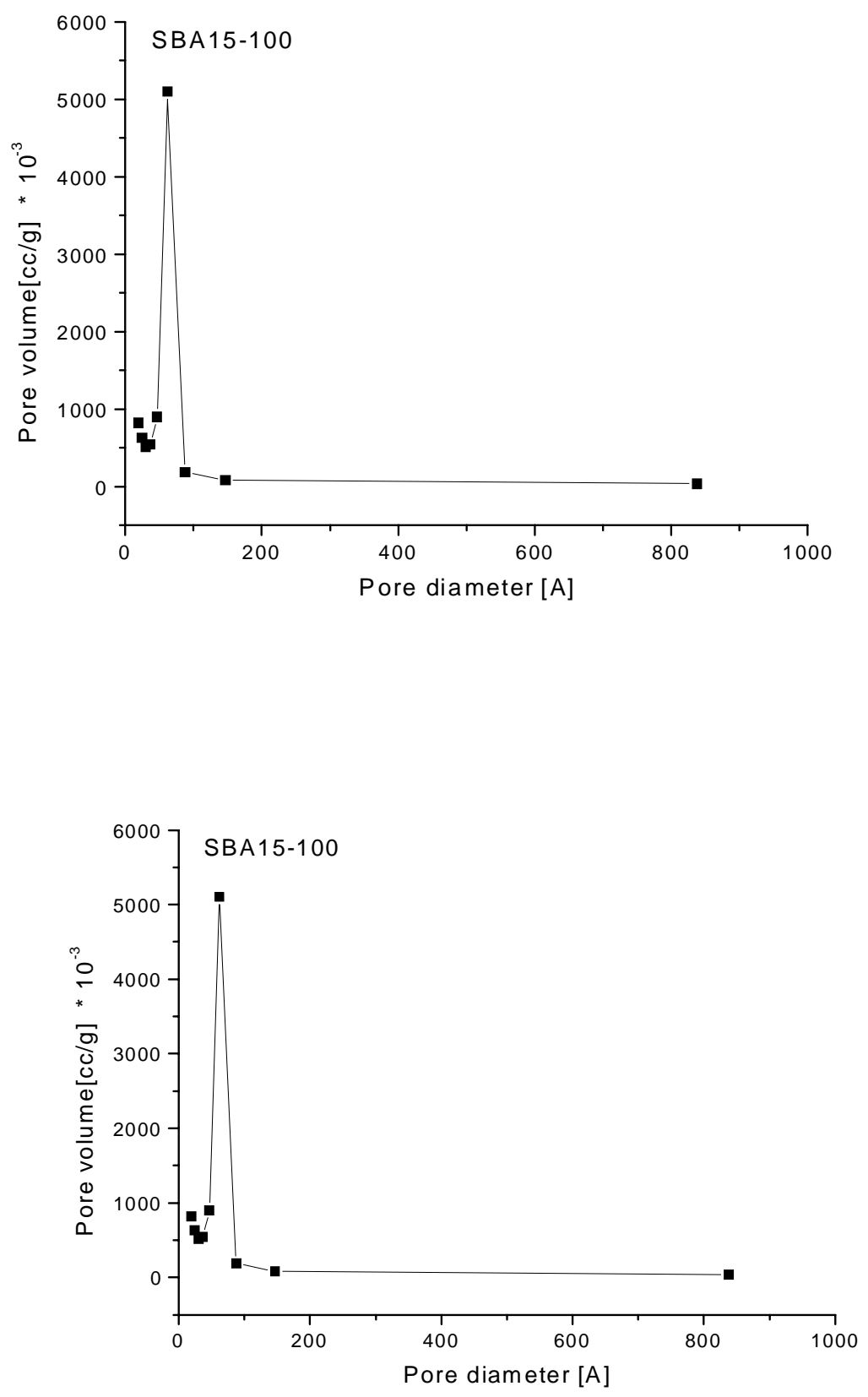

Figure 2 - Pore distribution of calcined $\mathrm{SBA}^{15-60} \mathrm{SBA}^{15-80} \mathrm{SBA}^{15-100}$ and $\mathrm{SBA}^{15130}$

All samples synthesized at different aging temperatures presented a narrow pore size distribution, as shown in Fig. 2.

The adsorption of the drug in different materials lead to a decrease in surface area and pore volume (Fig.1). These facts indicate that the the drug is present in the pores after the adsorption of atenolol. Indeed, as can be seen by analyzing the adsorption isotherms (Fig. 3) and BET results, the atenolol molecules do not fully occupy the available intrachannel space, a fact 
that can be attributed to a limited capacity of adsorption of the mesopores.

The presence of drug in the mesoporous wall was confirmed by FTIR (Fig. 4). The bands at
1509,02 and $1392,39 \mathrm{~cm}^{-1}$ are attributed to the presence of drug, and these IR absorbancies suggests the adsorption of the model drug in the mesoporous structure.

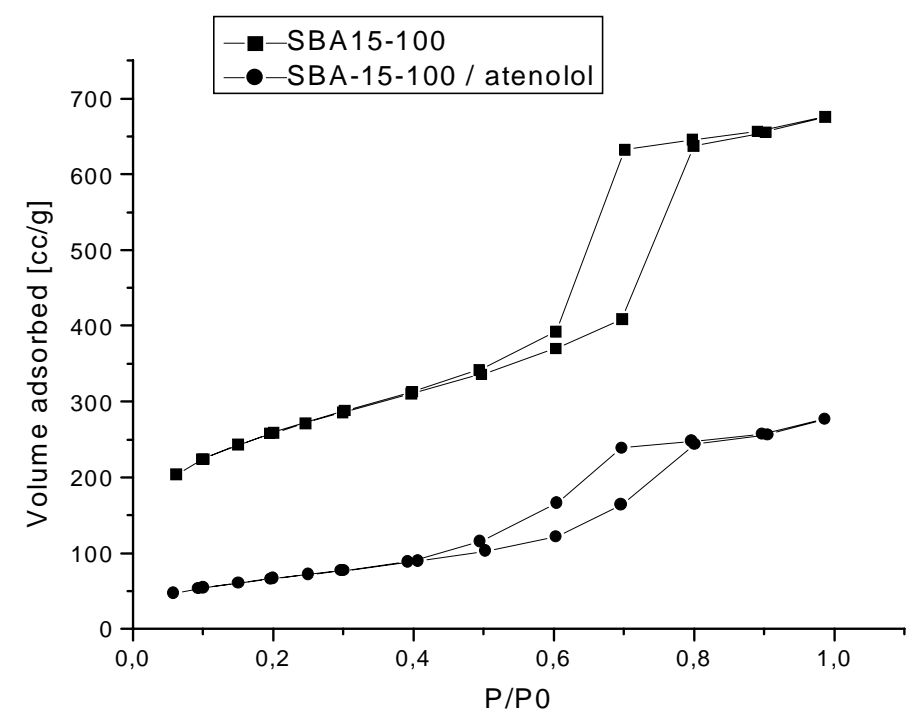

Figure 3 - Nitrogen adsorptions isotherms of calcined SBA15-100 and SBA15-100/atenolol

The in vitro drug release properties of mesoporous silica synthesized at $100{ }^{\circ} \mathrm{C}$ were investigated. The profile for release from the SBA15-100 matrix at $37^{\circ} \mathrm{C}$ for 10 hours is presented in Fig. 5.

It was observed that atenolol-loaded SBA15-100 did not show a sharp initial release burst during the first hours. The initial burst is attributed to the immediate dissolution and release of that portion of the drug located on and near the surface of the disks. This system presents a low rate of delivery, followed by a rather constant rate over the subsequent hours. This fact is possibly related to an interaction between the drug and the mesoporous silica by hydrogen bonding between the functional groups amine, amide and hydroxyl of atenolol and the silanol groups present on mesoporous silica.

The release of atenolol from the SBA15-100 matrix followed a diffusion-controlled model (Higuchi, 1963), where the quantity released per unit area is proportional to the square root of the time. A linear regression with the origin included among the data until 10 hours of release has been used to fit the data, with $r=f$ 0.999. The mechanisms of release from this system include the leaching of the drug by the bathing fluid, which is able to enter the drugmatrix phase through the pores. The drug is presumed to dissolve slowly into the liquid phase and diffuses from the system along the solvent-filled capillary channels. 


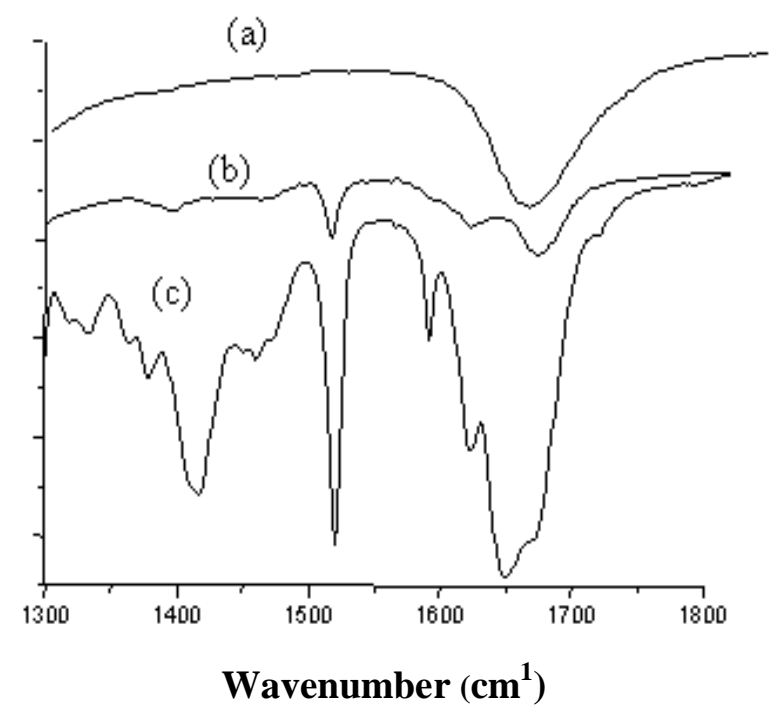

Figure 4 - FTIR spectra of (a) pure SBA15, (b) SBA-15 -atenolol, and (c) atenolol

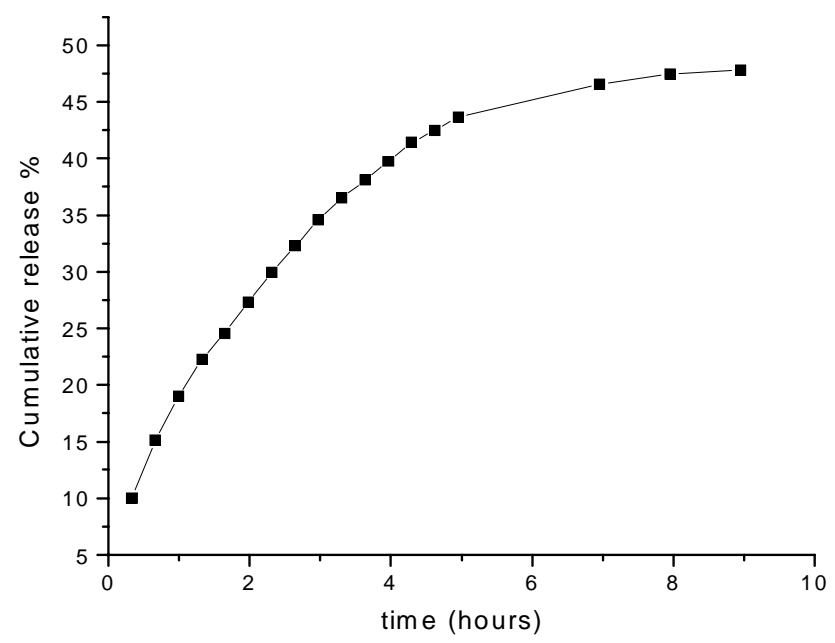

Figure 5 - Cumulative release profile of atenolol over 10 hours for SBA15-100.

\section{CONCLUSIONS}

The applicability of mesoporous silica SBA15 (hexagonal) materials as matrices for the controlled delivery of drugs was studied to establish the influence of the pore architecture and size on the atenolol release. The results indicated that mesoporous silica has a potential for encapsulating bioactive molecules by utilizing ordered mesopores.

The present study showed that the structural characteristics can be controlled by changes in 
synthesis temperature. It seems that sustained delivery of drug from this sample is obtained over a long period. The performance of the SBA- 15 for hosting radiopharmaceuticals was verified by using a model drug.

\section{RESUMO}

Recentes estudos conduziram à descoberta da sílica mesoporosa com estrutura hexagonal, que apresenta elevada área superficial $(700$ a 1000 $\left.\mathrm{m}^{2} / \mathrm{g}\right)$, tamanho de poros grande $(5$ a $9 \mathrm{~nm})$ e espessura fina de parede do poro $(3,5$ a $5,3 \mathrm{~nm})$, chamado SBA-15. Essas características fazem destes materiais matrizes adequadas para a incorporação e liberação controlada, sob condições apropriadas, de uma série de biomoléculas, principalmente radiofármacos. As características do SBA-15 preparado em diferentes temperaturas de envelhecimento e o comportamento desse sistema com relação ao micreoencapsulamento de uma droga modelo foi investigado. As amostras calcinadas foram conformadas em discos e imersas em uma solução saturada de atenolol, usado como droga modelo. A variação na temperatura de tratamento provoca algumas mudanças na estrutura dos poros, indicando a presença de microporosidade e interconectividade entre os mesoporos em condições específicas. Foi observado que materiais envelhecidos a elevadas temperaturas não apresentam microporosidades, e esse fato pode influenciar no controle da liberação da droga.

\section{ACKNOWLEDGEMENTS}

This work has been supported by $\mathrm{CNPq}$ and FAPEMIG.

\section{REFERENCES}

Doadrio, J. C.; Arcos, D.; Cabañas, M. V. and ValletRegí, M. (2004), Calcium sulphate-based cements containing cephalexin. Biomaterials, 25, 2629-2635.

Exner, A. A.; Krupka, T. M.; Scherrer, K. and Teets, J. M. (2005), Enhancement of carboplatin toxicity by Pluronic block copolymers. Journal of Controlled Release. [In press].
Galarneau, A. et. al. (2003), New J. Chem., 27, 73-79.

Hata, H. et al. (1999), Adsorption of Taxol into ordered mesoporous silicas with various pore diameters. Chem. Mater., 11, 1110-1119.

Higuchi, T. (1963), Mechanism of Sustained-Action Medication. J. Pharm. Sci., 52 ,1145-1147.

Kokubo, T.; Kushitani, H.; Sakka, S.; Kisugi, T.; Yamamuro, T.; Kokubo, T.; Kushitani, H.; Sakka, S.; Kitsugi, T. and Yamamuro, T. (1990), Solutions able to reproduce in vivo surface-structure changes in bioactive glass-ceramic A-W. J. Biomed. Mater. Res., 24, 721-734.

Krut, M.; Jaroniec, M.; Ko, C. H. and Ryo, R. (2000), Chem. Mater., 12, 1961.

Langer, R. (1999), Selected advances in drug delivery and tissue engineering. Journal of Controlled Release, 62, 7-11.

Luan, Z.; Hartmann, M.; Zhao, D.; Zhou, W. and Kevan, L. (1999), Chem. Mater., 11, 1621.

Marcucci, F. and Lefoulon, F. (2004), Active targeting with particulate drug carriers in tumor therapy: fundamentals and recent progress. Drug Discovery Today, 9, 219-228.

Moses, M. A.; Brem, H. and Langer, R. (2003), Advancing the field of drug delivery: Taking aim at cancer. Cancer Cell, 4, 337-341.

Ragel, C. V.; Vallet-Regi, M. and Rodriguez-Lorenzo, L. M. (2002), Preparation and in vitro bioactivity of hydroxyapatite/solgel glass biphasic material. Biomaterials, 23, 1865-1872.

Shin, Y.; Chang, J. H.; Liu, J.; Williford, R.; Shin, Y. K. and Exarhos, G. J. (2001), Hybrid nanogels for sustainable positive thermosensitive drug release. $J$. Controlled Release, 73, 1-6.

Sousa, E. M. B.; Doadrio, A. L.; Doadrio, J. C.; PerezPariente, J.; Izquierdo-Barba, I. and Vallet-Regí, M. (2004), Mesoporous SBA ${ }^{-15}$ HPLC evaluation for controlled gentamicin drug delivery. J. Control. Release, 97, 125.

Zeleňák, V.; Hrnebecq, V. and Llewellyn, P. (2005), Zinc(II)-benzoato complexes immobilised in mesoporous silica host. Microporous and Mesoporous Materials. [In press].

Zeng, W.; Qian, X. F.; Zhang, Y. B.; Jie, Y. and Zi-Kang, Z. (2005), Organic modified mesoporous $\mathrm{MCM}^{-41}$ through solvothermal process as drug delivery system. Materials Research Bulletin, 40, 766-772.

Zhao, D.; Huo, Q.; Fena, J.; Chemelka, B. F. and Stucky, G. D. (1998), J. Amer. Chem. Soc., 120, 6024.

Received: July 05, 2005; Revised: July 14, 2005 Accepted: August 01, 2005 